\title{
Study of Social Capital of KONI Community in the Sports Development in Central Java Indonesia
}

\author{
Tri Rustiadi
}

Department of Physical Education Health and Recreation, Semarang State University, Semarang, Central Java 50229, Indonesia

\begin{abstract}
Indonesian National Sport Committee, hereinafter called KONI, is the government body which has the authority to organize sport development in Indonesia. This study aims to analyze the social capital of regional KONI in Central Java which potentially support the implementation of the National Sport System Law. It also aims to analyze the relevant strategy to empower the social energy of KONI and to design the most appropriate model of KONI to solve problems raised after the law imposed. This study used qualitative approach with the idea of learning from people. This approach is a tool to understand the reality which moves the social capital of KONI. The result describes that the activities inside KONI reflect the reality of social capital. KONI as the social capital is a need for the development of the productive cooperation in the society. The existence of the article 40 might influence the characteristics of KONI as the social capital. The model of KONI as an organization of sport should be built in five potential elements: (1) democracy as an ideology, (2) freedom as a purpose, (3) empowerment as a function, (4) social justice as policy, and (5) discretion as a method.
\end{abstract}

Key words: Social capital, implementation of policy, the reality of KONI.

\section{Introduction}

This study focus on the analysis of social energy in the Indonesian National Sport Committee, hereinafter called KONI. KONI could be seen as the social capital which is potential in organizing, developing, and implementing the execution of National Sport System Law [1, 2]. The current studies about sport development have mainstreamed in the level of regulating the sport organization [3, 4]. The problem raised in the society is mainly about the deviation in the implementation of regulation, especially in terms of empowering society. These studies, however, could not solve the core of the problems [5].

The board of KONI is regulated by the article 40 of the National Sport System Law. The article 40 states that the board of the national sport committee, provincial sport committee, and regional sport committee shall be independent from structural officer or official public figure [2]. In the reality, there are

Corresponding author: Tri Rustiadi, M.Kes, research field: sport management. several things inappropriate with the implementation of the article 40. In the beginning of the implementation of article 40, there are still 11 governors and vice governors who became the chairman of provincial KONI though it is forbidden [2, 6-8]. It happens because the sport development in Indonesia still depends on the government budget. The existence of governor or mayor as the board of KONI will ease the budgeting allocation from the government [5].

The other reason of why the implementation of the article 40 is not optimized is that there is an opinion that the article 40 is discriminative. This article has been judicially reviewed through the Indonesian Constitution Court. The Constitution Court, however, rejected the judicial review of the article since the protest had no significant reason. The Court believed that the article 40 does not contradict any article of the Basic Laws 1945 as the basis of reference to review an article of law. The essence of the article 40 does not contain any violation or discrimination. The article 40 is useful to prevent the abuse of administration 
function. This rejection then makes the Constitution Court to consult with the Ministry of Youth and Sport to make a mechanism for the implementation of article 40 [5].

The law number 3/2005 about the national sport system is a legal instrument of sport development, the legal basis for all aspects of sports activities, the legal basis for security, protection, and legal assurance, the legal basis for all legislation and government policy as well as the legal basis for the existence of institutions mandated to be recognized or established, both government and non-government [2]. Furthermore, in the explanation of the article 40, it is stated that being independent means free from intervention of any party to maintain neutrality and to guarantee the professionalism of sports management. The structural position means a position that shows the duties, responsibilities, powers, and privileges of a civil servants and the military in order to lead the organizational units of government. The official public figure means a position that is obtained through a process of direct election by the people or through elections in the House of Representatives such as president, vice president, members of ministry, governor, mayor, and also members of parliament. Nevertheless, the law makes pros and cons argument coming from the sport community. Some parties believe that the decision of the Court would be extremely detrimental to the development of sport since there are still some chairman of provincial/regional KONI held by public officials because of budgeting policy. In the framework of the future development interests based on regional autonomy, the management model of such sport field is no longer functional. At this point, there is a systematic and conceptual effort to build a new model that is based on justice, shared prosperity, emancipation, participation, and avoiding conflict.

KONI can be seen as social capital because KONI was built as the result of a process that occurs in the community and have some basic elements. They are:
(1) the existence of social networks (involvement of the members of the group), (2) the existence of shared values, (3) the existence of shared norms, (4) the existence of friendship or social solidarity (social cohesion), (5) the existence of coordination and cooperation, and (6) the existence of a common goal or mutual benefit $[1,9,10]$. With these characteristics, KONI as social capital is a necessity for the creation of productive cooperation in a community, group, or an association.

Social capital can be defined as networks, norms, and trust that exist among the members of the community to facilitate cooperation for mutual benefit [11]. In this point of view, social capital is associated with a set of horizontal associations in the community. It consists of social networks and norms that associated with them which then give effect to the productivity of the community. Because social capital is a set of horizontal associations consisting of trust, norms, and networks that can facilitate cooperation for mutual benefit, then the function of social capital is to facilitate cooperation for mutual benefit for members of the association [8]. There are three important indicators of social capital, namely: (1) channels of information within a community, (2) the structure of authority, and (3) boundary conditions [9]. Information channel serves as an exchange network of ideas, aspirations and feelings among individual members of the community, while the authority structure serves to maintain order and stability, as well as a means of monitoring the activities of the members [12].

This study investigates the quality of the elements of social capital that exist in KONI. Changes in the characteristics of social capital in the KONI are expected to affect the performance of KONI [13]. However, the positive attitude shown by regional KONI towards the article 40 gives an optimism that the performance KONI is still able to be maintained. Researcher assesed whether changes in management as the implications of article 40 will make KONI 
perform less optimum or sustain its performance. KONI performance indicators can be seen through the effectiveness of the program implementation and achievement.

\section{Method}

This study used a qualitative approach. According to the procedure of qualitative research, the approach towards the research problems used Verstehen approach and interpretative understanding approach [14]. Through the Verstehen approach, we tried to understand the problems in the field of "what" and "how" reality KONI is, as well as to determine how is the implementation of the national sport system Law number 3/2005 from the point of view of "insiders" (fonemic) or emic understanding. This requires researcher to enter the world of conceptual "KONI members" in order to understand the trust, social networks, values, norms and authority structures that exist in the KONI community. This is easily done by researcher because researcher has become part of the KONI community during the last eight years. Through the interpretative understanding approach, we tried to understand the reality of KONI through the perspective of "outsiders" (fonetic) or understanding through etic interpretation. Through this etic interpretation, the particulars "why" and "when" of reality in the KONI community showed positive or negative response towards the implementation of the law [15].

The qualitative data collected in this study as well as its level of measurement consists of: (1) Trust, both among groups and among members of the KONI community. The quality of the trust is measured by the solidity of the trust built up; (2) Social Network, namely networking and communication intensity between KONI as a community with relevant government institutions, civil society, and among KONI members. The quality of social network is measured by the intensity of the communication conducted; (3) Shared Values, namely an agreement which is raised in the community regarding KONI ideal values. The quality of shared values is measured by the value orientation that is developed in the KONI community, as well as the difficulties and the necessity to build an ideal commitment; (4) Shared Norms, is a standard action of KONI community such as: ethical code and the code of conduct, both written and unwritten. The quality of shared norms are measured by the condition whether the written rules and unwritten customs that exist in the community are functioned or not; and (5) Structure of the Authority, the resolution of conflicts in the community when there is a conflict within KONI or the conflict with the wider community. The quality of authority structure is measured by the objectivity and rationality decisions taken.

This research was conducted at the regional KONI in Central Java. There are 35 regional KONIs, 47 Sport Branch Organizations, and 8 Functional Sport Organization Boards in Central Java. In Central Java province, there are Coordinating Boards (Bakorlin) which consist of three Bakorlin (Bakorlin 1, 2 and 3) and within each Bakorlin there are 12 or 11 regional KONIs. The determination of the sample is done by purposive sampling technique. From each Bakorlin, we took 2 to 3 KONIs that represent each Bakorlin. The data collection was done through combination of 4 techniques, namely: (1) in-depth interview, (2) Focus Group Discussion (FGD), (3) involved observation, and (4) semi-involved observation. The analysis model was carried out following the interactive model which requires researcher to engage in three cycles of activity, namely: data reduction, data presentation and conclusion or verification as something that intertwine both performed at the time before, during and after the field data collection [16].

\section{Results and Discussion}

The KONI reality was examined from various viewpoints. In terms of organizational board structure, the results of the documentation of KONI in seven 
regencies representing each Bakorlin in Central Java showed that generally regional KONI has no structural officer or official public figure in their board structure. There is only one, KONI Surakarta, which involves one public official from the legislative body who become deputy chairman of Surakarta regional KONI.

In terms of funding, in 2013, regional KONIs got the average funding of IDR 6 billion. The budget amount varied from IDR 450,000,000 to IDR 16.5 billion. The average amount of funding increased from the previous year, and some events got a budget increase quite dramatically from IDR 3.5 billion in 2012 to IDR 16.5 billion in 2013. It is only regional KONI of Kudus which decreased its budget from IDR 7.5 billion to IDR 4.7 billion. The source of the funding for all regional KONIs came from the regional reserve. There is no fund coming from another source.

The success of KONI can be assessed through the achievement of their athletes in any competition. All of regional KONIs targetted more medals in the Banyumas 2013 Provincial Sport Competition better than the target in the Surakarta 2009 Provincial Sport Competition. The regional KONI of Banyumas, for instance, targetted 110 golds in the 2013 provincial competition while it achieved 67 golds in the 2009 provincial competition.

In order to support the run of sport development in each region, KONI needs to have cooperation with another institution. However, most of regional KONI have no cooperation activities with other agencies. There were only regional KONI of Kudus, Banyumas, and Kebumen which have had partnership with companies. Koni of Kudus have a partnership with Djarum Kudus Ltd to provide scholarships for athletes and coaching support for the 45 badminton clubs in Kudus regency. KONI of Banyumas has partnership with the University of General Sudirman, a local university in Banyumas regency, to organize the use of sports facilities and to recruit potential athletes. It also has cooperation with SMA 3 Purwokerto, a famous senior high school in Banyumas regency, to open a sport class. KONI of Kebumen has cooperation with the regional sport office to manage the use of stadium.

In general, the regional KONIs carry out promotion activities in the form of health event, such as the series event to celebrate the Indonesian National Sport Day which involves the society at large scale. In addition, KONI also promotes its activities through the mass media. It was only KONI of Rembang which confirmed that it has no promotion activity. One of the outstanding programs of KONI is the outstanding athlete development program. Most of regional KONI hold athlete coaching in various sports. Some regional KONIs open sport class in collaboration with schools to recruit candidates of potential outstanding athletes, such as KONI of Wonogiri, Kebumen and Banyumas, while KONI of Rembang requires all schools in Rembang regency to open extracurricular sport class.

\subsection{Identification of Social Capital Elements and Its} Role

\subsubsection{Trust}

Researcher found that the reality of trust in regional KONI can be assessed through various indicators. The first indicator is decision making [17-19]. In general, regional KONI's decision is made through consultation and agreement within the member of the board. The chairman of the board always discusses every single decision of KONI to all members of the board before it is launched. It is only KONI of Kudus which said that though most of decisions in KONI of Kudus are taken by consensus, there are some occasions when the chairman takes decision by himself.

The second indicator is about the organization of duties [17-19]. In general, it is common that the chairman of regional KONI delegates some duties to his relevant staffs based on position and function. The staff would do the duty and report to the chairman. It is only KONI of Kudus which said that though that 
has been an organizational structure within the KONI, most of the duties of organization are done by the chairman himself since the chairman has enough time to focus on the organization.

The third indicator is the society aspiration accommodation [17-19]. The regional KONI always accommodate any aspirations coming from the sport society in each region. In the other hand, support from any agency or company is very important for the sustainability of KONI. However, most of KONI do not get any support or sponsorship from the other agency/company in the region. It is only KONI of Kudus, which get sustainable sponsorship from Djarum Kudus Ltd, a local big company in Kudus regency, to develop potential athletes and clubs. When we asked about the satisfaction of the company towards the partnership built with KONI, it confirmed that the company is satisfied with the cooperation.

Beside the sport events held by KONI, there are various events conducted by youth organizations or communities. They often proposed funding for the event to KONI. In the scheme of society aspiration accommodation, KONI accepts the proposal, reviews, and selects the appropriate proposal to be funded. The funding from KONI flows to those sport branches not uniformly, but according to the priorities and needs of the sport. It was only KONI of Pekalongan which distributes the fund uniformly to its sport branches. Each branch of sport gets IDR 20 million to be used for running sport events. Since the main source of the fund is the government reserve, then KONI reports the use of fund to the regional government. Some government offices need to be reported regarding the funding for KONI, including the office of youth and sport, the office of regional income and asset, the office of public welfare, and mainly to the regional office (mayor) itself. The use of the fund is also reported to the member of the board during the committee meeting forum.

\subsubsection{Social Network}

Social network is the element social capital which is assessed through the intensity of networking and communication [20-24] between KONI as a community with relevant government institutions, civil society, and among members of KONI. In order to strengthen the network, KONI usually do an institutional visit to its partner. Most of KONI do not make a regular visit. They only make a visit when it is necessary. The visit they have ever made was to the office of youth and sport, since this office is the government body which allocates the budget for KONI. In general, KONI has no relationship with supporter organization, though such organization exists. It was only Koni of Kudus which established partnership with the public relation of Djarum Kudus Ltd. Most of KONI holds discussion with sport branches management, such as KONI of Wonogiri, Rembang, and Surakarta. It can be held once in a quarter or in 2 months. During the discussion, KONI accommodate any complaint from the sport branches or from the society in general. KONI of Rembang, Pekalongan, Banyumas, and Kudus confirmed that there is no significant complaint which is needed to be followed up by KONI.

Most of regional KONI said that they do not depend on relations with the the company to obtain funding support for outstanding athlete development. However, KONI of Surakarta stated otherwise, that KONI depends on such relationship a lot. KONI of Pekalongan, Solo, and Surakarta have built the sports communication forum in which the public and interested parties could share their ideas. The other regional KONI also use social media to communicate with the community and members, such as KONI of Banyumas and Pekalongan. However, it is not all of regional KONI could persuade companies and donors to fund the development of outstanding athletes. It is only KONI of Kudus who can do that so far, since the company also needs to do the corporate social responsibility to the society. These donors are important to provide assistance exercise equipment at central coaching athletes. KONIs which have been 
supported by sports equipment are Kudus, Surakarta, and Kebumen.

\subsubsection{Shared Values}

Shared value is an agreement which is raised in the community regarding KONI ideal values [18-21]. Researcher has identified some ideal values which are held by KONI. The first value is honesty and transparent in financial report. All of the regional KONI always report the use of funds to its members and to the regional government. Though it is transparent, it is not an open source, then public could not access the financial statements of KONI. Some KONIs said that it is because there is no mechanism of financial reporting through the media.

The other value is togetherness. All of regional KONI said that most of members of the board are active member in the organized communication forum. KONI of Surakarta even confirmed that $100 \%$ of officials and members were present in the KONI forum. While most of regional KONI said that around $20 \%$ to $40 \%$ are passive in the outstanding athlete coaching, KONI of Surakarta claimed that $100 \%$ of its members are active in coaching excellent athletes.

\subsubsection{Shared Norms}

Shared norm is a standard of KONI community action, and/or the members of KONI, such as: etic code and code of conduct, both written and unwritten $[25,26]$. It can be seen from the way regional KONI follows its regulation. All of KONI has adhered to a code of ethics that is written in the constitution. Most of KONI said that the violation of the constitution can not be tolerated, for instance, stated by KONI of Pekalongan, Banyumas, and Rembang. Most of regional KONI claims that there is no structural or public officials who are in their management. It was only KONI of Surakarta which involved the legislative elements of the management. All of the KONI stated that when the period of the duty has been completed, KONI immediately hold a succession of organization. KONI also holds regular board meeting once a week, once a month, or once during 3 months.
Most of KONI have never held sports seminars. It was only KONI of Wonogiri and Kudus which held seminar on 2011. Most of KONI have never held sport workshop. It was only KONI of Wonogiri which held workshop in 2013 and KONI of Banyumas which conducted in 2012. It is also happen in terms of social service. It was only KONI of Kudus which has ever conducted a social service. While in terms of incentive for athletes, the average amount of incentive that KONI could accommodate varies from IDR 150,000 to IDR 1,000,000. KONI of Kebumen and Pekalongan, however, do not provide any incentives for the athletes but they help to organize sports events.

\subsection{Authority Structure}

The quality of authority structure is measured by the objectivity and rationality of decisions [27, 28]. All of the KONI feel fully responsible when the regency get minimum achievements in sports championships. All of the KONI set regulations so that local athletes have more opportunity to compete at the provincial level representing the region. Most of KONI restrict or even ban to bring in athletes from outside the region to represent the region in the provincial sport competition. The KONIs which do not limit them are Kudus, Banyumas and Pekalongan. All said that the Chairman of KONI is able to overcome any problems that occur among members of KONI.

\section{Conclusion and Recommendation}

The conclusions that can be obtained are that people in regional KONI in Central Java have limited ability of social capital to overcome the problems experienced by KONI. This is not primarily because of weak social capital they have (although for some parts is weak), but rather due to the nature of the experience of the organization. That is, the deficiency experienced by the people of KONI in Central Java is part dissolved in elements of social organization, network systems, value systems and so on. Social 
capital embodied in the form of cooperation (agencies, employers, society at large), social and cultural values, as well as the leadership has not been able to overcome the problem of the welfare of the citizens of KONI because of the structural constraints they experience.

Relevant strategies used in efforts to utilize social energy KONI City District in Central Java region can be an exit strategy, namely: (1) build trust as the basis of cooperation intra-community and inter-community; (2) strengthening institutional cooperation in the community in KONI organization; (3) improvement of the mechanism of aspiration and handling of information in the process of sports; (4) the development of structures of authority and leadership role KONI towards emancipatory; (5) the development of communication strategies; (6) integration of strategic alliance partners into the program in sports; (7) a direct approach to the target group and approach from various aspects. While the strategy to empower the social capital includes: (1) create a climate strengthen; (2) protect the appropriate development program for the community KONI; (3) The strategy of development of mutual cooperation; (4) Technical-professional development strategies; (5) conflict resolution strategies; and (6) cultural adaptation strategy.

Suggestions can be submitted in this research are: (1) social capital in the communities KONI districts/cities need to be developed further, so it would be able to carry out activities and in addressing the problems faced by KONI. The need for community empowerment program for KONI, the need for trainings that is comprehensive, the need for a program that is comprehensive and not partial, the implementation is from the member to the policy maker, necessary removal of prejudices unproductive among members of KONI, need to empower the potential of KONI organization for the benefit of themselves. Institutional role in community empowerment KONI is very important to enhance the role of community KONI. (2) Strategy community empowerment can be through the development of social communication, networking, trust, strategic partner alliances to integrate into programs KONI program, direct approach to the target group. In an effort to leverage social energy KONI Regency/City in Central Java region needs to take into account the socio-cultural strengthening, building confidence, and a strong network.

Furthermore, the idea of strengthening the social capital of KONI needs to be disseminated to the public especially related to the development of organizational model of KONI which is developed from the five main elements of potential support empowerment KONI as the main amplifier for the sporting community that includes elements of democracy as ideology, liberation as the goal, as a function of empowerment, social justice as policy the agenda, as well as a discretionary method.

\section{References}

[1] Owen, A. L., and Videras, J. 2009. "Reconsidering Social Capital: A Latent Class Approach.” Journal of Empirical Economics 37 (3): 555-82.

[2] Indonesian Ministry of Sport. 2005. The Law Number 3/2005 about National Sport System. Jakarta: Public Relation and Law Bureau. (in Bahasa Indonesia)

[3] Houlihan, B. 1997. Sport, Policy and Politics. London: Routlegde.

[4] Skinner, J. 2008. "Development through Sport." Journal of Sport Management 1 (1): 1-30.

[5] Indonesian Ministry of Sport. 2005. Indonesian Government Regulation Number 16/2007 about Sport Organization. Jakarta: Public Relation and Law Bureau. (in Bahasa Indonesia)

[6] Birawa. 2010. The Indonesian Minister of Sport Does not Mind If a Public Figure Lead KONI. Birawa News of Sport. (in Bahasa Indonesia)

[7] Jawa Pos. 2010. The Homework of KONI of East Java. News of the Week. (in Bahasa Indonesia)

[8] Top Skor. 2010. Rusli Zainal Takes Duty as the Chairman of KONI Riau 2009-2013. Report at the Provincial Sport Conference in Riau.

[9] Barros, C. P., and Alves, F. M. P. 2003. "Human Capital Theory and Social Capital Theory on Sports Management." International Advancer in Economic Research 1 (1): 218-26. 
[10] Glaeser, E. L. 2001. "The Formation of Social Capital." Canadian Journal of Policy Research 1 (1): 1-20.

[11] Putnam, D. 1993. Bowling Alone: The Collapse and Revival of American Community. New York: Simon and Schuster.

[12] Tan, T. K. 2001. "Social Capital and Legislative Institutions.” In Indonesian Parliament Manual. Jakarta: Yayasan Api. (in Bahasa Indonesia)

[13] Cheung, C. 2013. "Public Policies that Help Foster Social Inclusion." Social Indicators Research 112 (1): 47-68.

[14] Guba, E. G., and Lincoln, Y. S. 1994. "Competing Paradigms in Qualitative Research." In Handbook of Qualitative Research, edited by Denzin, N. K., and Lincoln, Y. S. London: Sage.

[15] Vaus, D. 2001. Research Design in Social Research. London: Sage.

[16] Moleong, L. J. 1996. Qualitative Research Method. Bandung: Rosda Karya, Ltd. (in Bahasa Indonesia).

[17] Fukuyama, F. 1996. Trust: The Social Virtues and The Creation of Prosperity. Harmondsworth: Penguin Books.

[18] Fukuyama, F. 1999. Social Capital and Civil Society. Presented at the IMF Conference on Second Generation Reforms, The Institute of Public Policy, George Mason University. Accessed May 18th, 2004. http://www.imf.org/external/pubsft/seminar/1999/ reforms/fukuyama.htm.

[19] Sobel, J. 2002. “Can We Trust Social Capital?” Journal of Economics Literature 40 (1): 139-54.

[20] Arthurson, K., Baum, F., and Ziersch, A. 2014. "Exploring Social Capital as Concept and Practice in Australian Public Health Policies and Programs." Australian Journal of Public Administration 73 (1): 79-87.

[21] Tonts, M. 2005. "Competitive Sport and Cosial Capital in Rural Australia.” Journal of Rural Studies 21 (1): 137-49.

[22] Syahra, R. 2003. "Concept and Application of Social Capital." Journal of Society and Culture 5 (1): 1-15. (in Bahasa Indonesia)

[23] Narayan, D. L. P. 1997. Cents and Sociability: Household Income and Social Capital in Rural Tanzania. Washington DC: World Bank.

[24] Illingworth, P. 2012. "Ethics and Social Capital for Global Well-being." Review of Economics 59 (4): 389-407.

[25] Basah, S. 1986. Three Writing of Law. Bandung: Armico. (in Bahasa Indonesia)

[26] Darmodihardjo, D., and Sidharta. 1996. Principles of Law Philosophy, What and How the Indonesian Law Is. Jakarta: Gramedia Pustaka Utama. (in Bahasa Indonesia)

[27] Department of National Education. 2003. An Analysis of Sport, Policy, and Politics. Jakarta: Department of National Education. (in Bahasa Indonesia)

[28] Wignjosoebroto, S. 2002. Paradigm, Method, and Problem Dynamic of Law. Jakarta: ELSAM. (in Bahasa Indonesia) 